\title{
ANALYSIS OF THE SUSTAINED VIROLOGICAL RESPONSE IN PATIENTS WITH CHRONIC HEPATITIS C AND LIVER STEATOSIS
}

\author{
Leonora De Zorzi PICCOLI', Angelo Alves de MATTOS ${ }^{1}$, Gabriela Perdomo CORAL', \\ Ângelo Zambam de MATTOS ${ }^{1}$ and Diogo Edele dos SANTOS ${ }^{2}$
}

\begin{abstract}
Context - Chronic hepatitis C as well as non-alcoholic fatty liver disease are recognized as the main cause of liver disease in Western countries. It is common to see the concomitance of the diseases and the influence of steatosis in the sustained virological response of patients with hepatitis C virus. Objective - Assess the sustained virological response in chronic hepatitis C patients according to the presence of liver steatosis. Methods - One hundred sixty patients with chronic hepatitis C were retrospectively evaluated. Demographic data such as gender, age, body mass index, presence of diabetes mellitus and systemic arterial hypertension, virus genotype and use of pegylated interferon were analyzed, as was the staging of fibrosis and the presence of steatosis at histology. Results - Most patients were male (57.5\%), with a mean age of $48 \pm 9.7$ years. The most frequent genotype observed was $3(56.9 \%)$ and, in the histological evaluation, steatosis was observed in $65 \%$ of the patients (104/160). Sustained virological response in patients with steatosis occurred in $38.5 \%$, and in $32.1 \%$ in patients without steatosis $(P=0.54)$. When we analyzed possible factors associated with the presence of steatosis, only body mass index and systemic arterial hypertension revealed a significant association. When the factors that influenced sustained virological response were evaluated in a logistic regression, genotype and use of pegylated interferon proved to be independent factors associated to the response. Conclusion - In the evaluated patients the presence of liver steatosis did not influence the sustained virological response of patients with chronic hepatitis $\mathrm{C}$ treated with interferon and ribavirin.
\end{abstract}

HEADINGS - Hepatitis C, chronic. Fatty liver. Antiviral agents.

\section{INTRODUCTION}

Non-alcoholic fatty liver disease (NAFLD) is a pathological clinical syndrome that ranges from isolated liver steatosis to non-alcoholic steatohepatitis (NASH), which can progress to advanced fibrosis and cirrhosis ${ }^{(7)}$. Estimates based on imaging studies and autopsies suggest that approximately $20 \%-30 \%$ of American adults and those from Western countries have an accumulation of liver fat ${ }^{(3,6,7,15,46)}$, and approximately $10 \%$ of these individuals have NASH. This is frequently associated with adult age, female gender, obesity, diabetes mellitus (DM) type 2, hypertriglyceridemia, dyslipidemia and other conditions characterized by resistance to insulin and hyperinsulinemia ${ }^{(7,11,52)}$. A study conducted by our group ${ }^{(60)}$ demonstrated that NASH is also a common disease among obese, non-diabetic patients, with altered levels of aminotransferases, occurring in $3.18 \%$ and, as a rule, presenting itself as a mild disease, although more intense cases may also be observed.

Liver steatosis is one of the most frequent histological findings in chronic hepatitis $\mathrm{C}(\mathrm{CHC})$ patients, observed in approximately $55 \%$ of those patients ${ }^{(1,8,14,19,26,28,29,37}$, $40,42,43,45,49,59)$. In a recent study, Coral et al. ${ }^{(17)}$ revealed steatosis in $55 \%$ of the patients infected by hepatitis $\mathrm{C}$ virus (HCV), correlating with genotype 3 , but not with the degree of liver fibrosis.

The mechanisms through which the HCV causes liver damage associated with steatosis are poorly understood. It seems that the accumulation of fat in the hepatocytes of patients with $\mathrm{CHC}$ occurs mainly due to an effect of the virus itself strengthened by metabolic factors related to the host ${ }^{(19,42,50,53)}$. The virus interferes with genes expression increasing de novo fatty acids synthesis and decreasing both hepatocyte lipids export and fatty acids consumption (oxidation). It seems that HCV increases the production of TNF (tumor

Study conducted at the Gastroenterology and Hepatology Unit of Universidade Federal de Ciências da Saúde de Porto Alegre (UFCSPA), Porto Alegre, RS, Brasil.
${ }^{1}$ Post-Graduate Course in Hepatology of UFCSPA; ${ }^{2}$ Hospital Santa Casa de Misericórdia de Porto Alegre, RS, Brasil.

Correspondence: Prof. Angelo Alves de Mattos - Rua Cel. Aurélio Bitencourt, 35/201 - 90430-080 - Porto Alegre, RS, Brasil. E-mail: angeloamattos@gmail.com 
necrosis factor), leading to insulin resistance: TNF probably affects insulin receptor substrate (IRS-1) phosphorylation, decreasing glucose captivation and promoting compensatory hyperinsulinemia. Besides this, it is possible that liver siderosis and alterations in the levels of circulating adipocytokines might as well have a role in insulin sensitivity in $\mathrm{CHC}^{(39)}$. Nevertheless, Mello et al. ${ }^{(35)}$ failed to find an enhancement in insulin resistance, evaluated by HOMA (homeostatic model assessment), with the treatment of $\mathrm{HCV}$.

There is agreement among several authors that the physiopathology of liver steatosis associated with $\mathrm{HCV}$ is different in patients infected by genotype 1 or $3^{(4,12,23,31,47,49)}$. Thus, the association between CHC and steatosis in patients infected by HCV genotype non-3, especially in those with genotype 1 , seems to be related to pre-existing factors of the host, and is called "metabolic steatosis". In this group of patients, the intensity of fat accumulation is proportional to BMI and the degree of visceral obesity, and there is no improvement after negativation of the virus through antiviral treatment ${ }^{(13,33)}$. On the other hand, in patients with $\mathrm{HCV}$ genotype 3, steatosis is related to higher viral loads and usually decreases after HVC treatment; this virus probably leads to hypobetalipoproteinemia, affecting liver release of triglycerides in bloodstream as VLDL (very low density lipoprotein) $)^{(39)}$.

The presence and intensity of liver steatosis is considered a marker of liver disease progression in patients with $\mathrm{CHC}$, and it also seems to have an impact on sustained virological response (SVR) in these patients when submitted to antiviral therapy ${ }^{(48,53)}$. It is possible that hyperinsulinemia could block the inhibition of $\mathrm{HCV}$ replication by interferon, since insulin and interferon share signal transduction factors, such as p38 MAP kinase; PI3 kinase and IRF-1 also might be associated ${ }^{(18,39)}$.

The main objective of this study was to assess SVR in patients with $\mathrm{CHC}$ and to relate it to the presence of hepatic steatosis.

\section{METHODS}

This is a retrospective study in which medical records of patients with $\mathrm{CHC}$ were assessed after they had undergone liver biopsy between January 2001 and December 2006, at Hospital Irmandade Santa Casa de Misericórdia de Porto Alegre, RS, Brasil.

The criteria for inclusion were: be over the age of 18 , be infected by HCV, have undergone a liver biopsy, have concluded treatment with conventional or pegylated interferon associated with ribavirin at least 6 months prior to data collection with the intent of evaluating sustained virological response. Currently, in Brazil, the Public Health System provides treatment for naïve $\mathrm{CHC}$ patients with pegylated interferon if $\mathrm{HCV}$ genotype-1 and with conventional interferon if other genotypes of $\mathrm{HCV}$.

In order to avoid possible confusion factors, daily alcohol consumption of more than or equal to $40 \mathrm{~g} /$ day for men and $20 \mathrm{~g} / \mathrm{day}$ for women and other causes of liver disease such as infection by hepatitis B virus, auto-immune hepatitis, hemochromatosis, Wilson's disease, alpha 1-antitrypsin deficiency and use of hepatotoxic medications were considered criteria for exclusion. Patients with decompensated liver disease, patients infected with HIV, patients with renal insufficiency and patients with any sort of neoplasia were also excluded. Other criteria for exclusion were liver biopsies with histological representation of less than seven portal spaces and incomplete medical records.

All patients had their diagnosis of $\mathrm{HCV}$ infection confirmed by $\mathrm{PCR}^{(56)}$ and genotyping was conducted by restriction fragment length polymorphism technique ${ }^{(55)}$.

Age, gender, body mass index (BMI - using the weight $/$ height $^{2}$ formula $)^{(16)}$, presence of DM (defined as fasting glycemia greater than or equal to $126 \mathrm{mg} / \mathrm{dL}$ in at least two measurements) ${ }^{(5)}$, presence of SAH - systemic arterial hypertension (defined as systolic blood pressure - BPs - greater than or equal to 140 $\mathrm{mm} \mathrm{Hg}$ or diastolic blood pressure - BPd - greater than or equal to $90 \mathrm{~mm} \mathrm{Hg})^{(51)}$ and the serum levels of the following exams were evaluated: aminotransferases, total cholesterol, HDL (high density lipoproteins), triglycerides and $\gamma$-GT.

With regard to BMI, it was considered normal a BMI less than or equal to $25 \mathrm{~kg} / \mathrm{m}^{2}$; overweight, BMI between 25.1 and $29.9 \mathrm{~kg} / \mathrm{m}^{2}$; and obesity, BMI greater than or equal to $30 \mathrm{~kg} / \mathrm{m}^{2}$. Two groups were considered for statistical analysis: BMI $\leq 25 \mathrm{~kg} / \mathrm{m}^{2}$ and $\mathrm{BMI}>25 \mathrm{~kg} / \mathrm{m}^{2}$.

The type of treatment conducted, interferon $\alpha$ and ribavirin or pegylated interferon and ribavirin, was also considered. In order to analyze response to treatment, two groups were considered: those who achieved SVR when the qualitative RNA-HCV was negative in the 6th month after conclusion of treatment and the non-responders, patients who did not have a $2 \log$ drop in quantitative RNA-HCV in week 12, patients who did not negativate qualitative RNA-HCV at the end of treatment or who had a positive qualitative RNA-HCV in the 6th month after conclusion of the same (recurrents).

Liver fragments obtained in liver biopsies were colored with $\mathrm{H}-\mathrm{E}$, picrosirius and Prussian blue dyes to assess steatosis and inflammatory activity, liver fibrosis and iron load, respectively.

The Metavir ${ }^{(30)}$ classification was used for chronic hepatitis $\mathrm{C}$ and the Brunt ${ }^{(11)}$ classification for NAFLD. For statistical analysis, the patients were divided into two groups according to degree of fibrosis: absence of fibrosis to moderate fibrosis (F0-F1-F2) and intense fibrosis (F3-F4).

NASH was defined according to the American Association for the Study of Liver Diseases classification ${ }^{(11)}$.

All biopsies were reviewed by a single pathologist who did not know the patients' clinical and laboratory data.

The study was submitted to and approved by the Ethics Committee of the Hospital Irmandade Santa Casa de Misericórdia de Porto Alegre.

Age, weight, height and body mass index were analyzed as means and standard deviation. Laboratory exams such as serum glycemia, aminotransferases and $\gamma$-GT were also calculated as means and standard deviation. The sustained 
virological response was calculated by frequency and percent, generating an SVR rate. Other categorical variables were also expressed in frequency and percent. The association of the variables and SVR was evaluated by OR - odds ratio, with a $95 \%$ confidence interval. Chi-square or Fisher's exact test were used when necessary. Potential confusion effects were removed in a logistics regression model and a $5 \%$ index of significance was adopted $(\alpha=0.05)$. The statistical analysis was done using the SPSS 12.0 package.

\section{RESULTS}

Of a total of 396 patients with $\mathrm{CHC}, 120$ did not meet the criteria for inclusion: 24 for being in treatment during the data collection period; 2 because they suspended treatment before completing it due to intolerance; 28 for being HIV-positive; 11 for having concomitant hepatitis B virus; 4 for undergoing lung and kidney transplants during the study period; 8 for having several types of neoplasia (including a case of hepatocellular carcinoma); 3 patients with decompensated cirrhosis; 4 alcohol abusing patients; 18 patients with chronic renal insufficiency who were undergoing treatment with interferon in monotherapy; and 18 patients with chronic renal insufficiency whose liver biopsy was considered insufficient.

Ninety-six patients were also excluded from the protocol for not having any indication of treatment during this period and 20 patients for incomplete data because they had missed follow-ups at the clinic.

Thus, 160 patients met the previously established criteria of inclusion and were evaluated for this study.

The majority of patients was male (92/160 - 57.7\%) and mean age was 48 years, with a standard deviation of 9.7. The mean weight of the patients was $73.66 \mathrm{~kg}$, with a standard deviation of $13.58 \mathrm{~kg}$. Mean height was $1.68 \mathrm{~m}$, with a standard deviation of $0.09 \mathrm{~m}$. Mean body weight index was $26.07 \mathrm{~kg} / \mathrm{m}^{2}$, with a standard deviation of $4.5 \mathrm{~kg} / \mathrm{m}^{2}$. These data and those that refer to the laboratory exams can be appreciated in Table 1 .

TABLE 1. Demographic characteristics and laboratory data of evaluated patients

\begin{tabular}{lcc}
\hline Characteristics & Mean & Standard deviation \\
\hline Age (years) & 48 & 9.7 \\
Weight $(\mathrm{kg})$ & 73.66 & 13.58 \\
Height $(\mathrm{m})$ & 1.68 & 0.09 \\
BMI $\left(\mathrm{kg} / \mathrm{m}^{2}\right)$ & 26.07 & 4.5 \\
Fasting glycemia $(\mathrm{mg} / \mathrm{dL})$ & 96.74 & 26.04 \\
ALT $(\mathrm{mg} / \mathrm{dL})$ & 111.94 & 94.61 \\
AST $(\mathrm{mg} / \mathrm{dL})$ & 76.86 & 56.96 \\
$\gamma$-GT $(\mathrm{mg} / \mathrm{dL})$ & 93.32 & 124.97 \\
Total cholesterol $(\mathrm{mg} / \mathrm{dL})$ & 163.27 & 39.33 \\
HDL cholesterol $(\mathrm{mg} / \mathrm{dL})$ & 45.35 & 12.1 \\
Triglycerides $(\mathrm{mg} / \mathrm{dL})$ & 109.85 & 48.79 \\
\hline
\end{tabular}

$\mathrm{BMI}=$ body mass index
Of the 160 patients studied, genotype 3 was the most prevalent, being found in 91 patients $(56.9 \%)$, while genotype 1 was found in 60 patients $(37.5 \%)$, and genotype 2 , in 9 patients $(5.6 \%)$.

In the analysis of liver biopsy, grade 0 fibrosis was found in 3 patients (1.9\%); grade 1 fibrosis, in $31(19.4 \%)$; grade 2 fibrosis, in 68 patients (42.5\%); grade 3 fibrosis, in $34(21.3 \%)$; and grade 4 fibrosis, in $24(15 \%)$. Most patients $(102-63.8 \%)$ belonged to the absent fibrosis to moderate fibrosis group.

Analyzing the degree of steatosis found in liver biopsies, steatosis was observed to be present in 104/160 patients $(65 \%)$. Among these, $76(47.5 \%$ ) presented steatosis in less than 33\% of the hepatocytes, that is, grade 1 steatosis; 21 patients (13.1\%) had between $33 \%$ and $66 \%$ of the hepatocytes with steatosis, that is, grade 2 ; and 7 patients $(4.4 \%)$ presented more than $66 \%$ of their hepatocytes with steatosis, characterizing grade 3 steatosis. Among the patients with steatosis, in 98/104, it was macrovesicular, which represents $94.2 \%$. Mixed steatosis was observed in $6 / 104$, representing $5.8 \%$ of the sample.

The presence of NASH was only observed in eight patients studied $(5 \%)$ and, for that reason, this data was not submitted to statistical analysis.

Among patients with genotype 3 , steatosis was observed in 64/91 patients $(61.5 \%)$. In the other genotypes, the presence of steatosis was observed in 40/69 (38.5\%) patients.

DM was found in 19 patients, which represents $11.9 \%$ of the sample studied. Twenty-four patients $(15 \%)$ were diagnosed with arterial hypertension.

When the antiviral treatment used by the patients was analyzed, only $48(30 \%)$ patients had undergone treatment with pegylated interferon associated with ribavirin. Conventional interferon associated with ribavirin was the treatment of choice for $70 \%$ of the patients $(112 / 160)$.

In analysis of the virological response, SVR was found in 58 patients, representing $36.3 \%$ of the sample, while nonresponders represented 73 patients $(45.6 \%)$, and recurrents, 29 patients $(18.1 \%)$.

The results found, in accordance with group characteristics, taking into account the presence of steatosis, are shown in Table 2 .

TABLE 2. Characteristics analyzed in relation to the presence of steatosis

\begin{tabular}{lccc}
\hline Characteristics & $\begin{array}{c}\text { Steatosis } \\
\mathrm{n}=104(65 \%)\end{array}$ & $\begin{array}{c}\text { Without steatosis } \\
\mathrm{n}=56(35 \%)\end{array}$ & $P$ \\
\hline Age $>40$ years & $89(85.6 \%)$ & $41(73.2 \%)$ & 0.09 \\
BMI $>25 \mathrm{~kg} / \mathrm{m}^{2}$ & $65(62.5 \%)$ & $18(32.1 \%)$ & $<0.01$ \\
Genotype & & & 0.08 \\
1 & $37(35.6 \%)$ & $23(41.1 \%)$ & \\
2 & $3(2.9 \%)$ & $6(10.7 \%)$ & \\
3 & $64(61.5 \%)$ & $27(48.2 \%)$ & \\
Fibrosis & & & 0.45 \\
0.1 and 2 & $69(66.3 \%)$ & $33(58.9 \%)$ & \\
$\quad 3$ and 4 & $35(33.7 \%)$ & $23(41.1 \%)$ & \\
Diabetes & $11(10.6 \%)$ & $8(14.3 \%)$ & 0.66 \\
SAH & $22(21.2 \%)$ & $2(3.6 \%)$ & 0.01 \\
\hline
\end{tabular}

$\mathrm{BMI}=$ body mass index

$\mathrm{SAH}=$ systemic arterial hypertension 
TABLE 3. Evaluated factors and their relation with sustained virological response

\begin{tabular}{|c|c|c|c|c|c|}
\hline \multirow{2}{*}{ Characteristics } & \multirow{2}{*}{$\mathrm{n}$} & \multirow{2}{*}{ SVR } & \multicolumn{3}{|c|}{ Logistic regression } \\
\hline & & & OR & CI95\% & $P$ \\
\hline \multicolumn{6}{|l|}{ Steatosis } \\
\hline Yes & 104 & $40(38.5 \%)$ & 1.5 & 0.7 to 3.4 & 0.29 \\
\hline No & 56 & $18(32.1 \%)$ & & & \\
\hline \multicolumn{6}{|l|}{ Age } \\
\hline$\geq 40$ & 130 & $41(31.5 \%)$ & 0.3 & 0.1 to 0.8 & 0.33 \\
\hline$<40$ & 30 & $17(56.7 \%)$ & & & \\
\hline \multicolumn{6}{|l|}{ BMI } \\
\hline$\geq 25$ & 83 & $30(31.5 \%)$ & 0.8 & 0.4 to 1.6 & 0.50 \\
\hline$<25$ & 77 & $28(36.4 \%)$ & & & \\
\hline \multicolumn{6}{|l|}{ Genotype } \\
\hline 1 & 60 & $17(28.3 \%)$ & 6.1 & 1.6 to 22.7 & $<0.01$ \\
\hline 2 and 3 & 100 & $41(41.0 \%)$ & & & \\
\hline \multicolumn{6}{|l|}{ Fibrosis } \\
\hline 0,1 and 2 & 102 & $40(39.2 \%)$ & 0.7 & 0.3 to 1.4 & 0.26 \\
\hline 3 and 4 & 58 & $18(31.0 \%)$ & & & \\
\hline \multicolumn{6}{|l|}{ Peg-interferon use } \\
\hline Yes & 48 & $20(41.7 \%)$ & 7.2 & 1.9 to 22.4 & $<0.01$ \\
\hline No & 112 & $38(33.9 \%)$ & & & \\
\hline
\end{tabular}

SVR = sustained virological response

$\mathrm{OR}=$ odds ratio

$\mathrm{CI}=$ confidence interval

Analyzing liver steatosis and its relation to SVR, it was observed that from 104 patients who had liver steatosis in the biopsy, $40(38.5 \%)$ had SVR, whereas in the group of patients without steatosis this number was $18 / 56(32.1 \%)$, with no statistical difference. These data and those that refer to the relation between SVR and age, BMI, genotype, grade of fibrosis and type of interferon used can be analyzed in Table 3.

This study revealed that, in genotype 1, the presence of steatosis was associated with SVR in 14/37 (11.2\%) versus $2 / 23(2.98 \%)$ without steatosis $(P=0.06)$. In patients with genotypes 2 and 3 who achieved SVR, steatosis was present in $33 \%(26 / 67)$ versus $34.2 \%(15 / 33)$ of those without steatosis $(P=0.99)$.

\section{DISCUSSION}

There is a study that suggests that steatosis can induce a mechanism of resistance to antiviral therapy ${ }^{(42)}$. This mechanism is still unknown, but it seems to be independent of other known response factors, such as genotype 1, high viral load and extensive fibrosis as well as metabolic factors. This mechanism also seems to be specific of the so-called "metabolic steatosis", since the "viral steatosis" observed in genotype 3 is not associated with a low rate of sustained virological response.

The negative effect of steatosis on the response to antiviral treatment may be caused by the reduction in bioavailability of antiviral drugs and/or host factors, such as more advanced disease and/or coexistence of other associated diseases ${ }^{(55)}$. Another possible explanation for steatosis' interference in the response to antiviral treatment is associated with resistance to insulin, considering the "two stage" hypothesis suggested by Day et al. ${ }^{(20)}$, in 1998. It is possible that hyperinsulinemia blocks inhibition of $\mathrm{HCV}$ mediated by interferon, by interacting with interferon's regulator factor, impeding its activation ${ }^{(31)}$.

Liver steatosis is present in around $55 \%$ of patients infected by $\mathrm{HCV}$, varying between $40 \%$ and $86 \%$ of the cases ${ }^{(36,43)}$. In the present casuistics, steatosis occurred in $65 \%$ of the patients, which is in agreement with the data found in literature ${ }^{(42)}$.

In a general sense, steatosis present in patients infected by $\mathrm{HCV}$ is grade 1 , affecting less than $33 \%$ of the hepatocytes ${ }^{(8,12,17}$, ${ }^{45)}$, which was also found in this study ( $47.5 \%$ of the biopsies).

This study did not show any significant association between age and the presence of steatosis, but did with BMI, which was

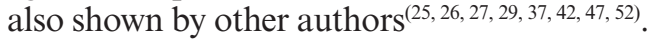

There is a tendency to associate the hepatitis $\mathrm{C}$ genotype

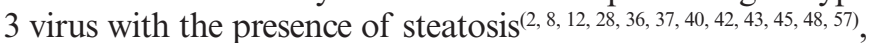
also found in this study, in which $61.5 \%$ of HCV genotype 3 patients had steatosis in the biopsy. The presence of steatosis was observed in fewer patients with genotypes other than 3 . However, despite the higher prevalence of steatosis in genotype 3 , there was no statistical difference among groups. Unfortunately, it was not possible to evaluate the existence of a relation between $\mathrm{HCV}$ genotype 3 viral load and steatosis, since Brazilian Public Health System does not provide viral load measurements for this genotype.

Some authors ${ }^{(1,36,43)}$, when seeing an association between liver steatosis and genotype 3, suggested that a specific viral sequence of this genotype could be responsible for this "steatotic phenotype". It must be pointed out that improvement in steatosis 
is associated with the negativation of the HCV genome in the hepatocyte.

Rubbia-Brandt et al. ${ }^{(44)}$ confirmed, in a multivariate analysis, that the association between the presence and severity of liver steatosis in patients infected by genotype 3 is not fortuitous, since HCV genotype 3 patients had a tenfold greater chance of presenting liver steatosis in biopsy, regardless of other factors such as alcohol use, overweight/obesity and use of injectable drugs.

With regard to the relationship between steatosis and liver fibrosis, several studies have demonstrated a positive association ${ }^{(19}$, ${ }^{26,29)}$. Studies that evaluated sequential liver biopsies proved this association $^{(12,22,57)}$. Thus steatosis has been considered a co-factor for liver fibrosis. In the casuistics under study, and as referred by other authors ${ }^{(8,32)}$, an association was not demonstrated between the presence of steatosis and fibrosis.

The relationship between the metabolic syndrome and the presence of liver steatosis is well-known. Furthermore, common findings of this syndrome, such as obesity, diabetes, arterial hypertension and hypertriglyceridemia, are strongly associated with the presence of NAFLD in CHC patients ${ }^{(47)}$.

In our study, the presence of DM was only observed in 19 patients, without any relationship between this finding and the presence of steatosis. This fact is believed to result from the small number of cases with diabetes. However, it was possible to demonstrate that the presence of systemic arterial hypertension was related to the finding of liver steatosis.

In this study, $36.3 \%$ of the patients achieved SVR, which is in agreement with the values found in a previous study conducted by our group ${ }^{(21)}$.

In relation to SVR, of the diverse parameters evaluated, only genotype and pegylated interferon use in antiviral treatment achieved statistical significance in a multivariate analysis. BMI, age, fibrosis and steatosis did not correlate with SVR in this analysis.

The mechanisms through which obesity can affect response to antiviral treatment are not totally understood. BMI has been related to the degree of steatosis observed in chronic hepatitis $\mathrm{C}^{(10,26)}$. Bressler et al. ${ }^{\left({ }^{(1)}\right)}$ demonstrated that obesity, defined as BMI $>30 \mathrm{~kg} / \mathrm{m}^{2}$, is a risk factor for non-response to antiviral treatment, regardless of genotype and the presence of liver cirrhosis. In this study, BMI was not associated with SVR, as in other studies ${ }^{(40,42)}$.

Most of the patients in this study were over 40 years of age, which could probably be one of the factors to explain the population's low SVR. In younger patients, SVR was found in $56.7 \%$ corroborating the fact that age is related to response to treatment in patients infected by $\mathrm{HCV}^{(9,24,33,34,40,61)}$. However, it must be underscored that no association was found between age and SVR in this study.

When analyzing liver fibrosis, no statistically significant correlation was found between the grade of fibrosis and SVR, although patients with lower grades of fibrosis obtained a better SVR ${ }^{(38,41)}$.

In the casuistics in question, the presence of steatosis did not exert any influence on SVR, different from what was found in other studies ${ }^{(40,42)}$. It is possible that it could relate to a typeII error, since our study has a smaller sample than others, but, recently, it has been published some data corroborating our findings. Cross et al. ${ }^{(18)}$, for instance, found that only $\mathrm{HCV}$ genotype and pretreatment weight were associated to SVR in a multivariate analysis; neither statosis, nor steatohepatitis were considered independently associated with this outcome. It is possible, then, that pretreatment weight and not steatosis would affect the treatment results; nevertheless, we did not find association between BMI and SVR either.

As in literature ${ }^{(24,31,34,42,53)}$, in a multivariate analysis, this study demonstrated that patients with HCV genotypes 2 and 3 had a better SVR rate when compared to those with genotype 1.

Westin et al. ${ }^{(58)}$, in a European multicentric study, demonstrated that $88 \%$ of the genotype 3 patients obtained SVR, regardless of the high prevalence of steatosis and pretreatment viral load found in this group. In genotypes other than 3, a 56\% SVR rate was found, and, in patients with steatosis, this rate was of $46 \%$, whereas, in those without steatosis this rate was of $65 \%$, demonstrating the impact of steatosis on SVR in these patients. This group suggests that weight loss should be the objective of an intervention in the patients' life habits with the intent of creating better conditions for antiviral therapy success.

The improvement in SVR rate has been demonstrated by several authors when the antiviral treatment of choice is pegylated interferon associated with ribavirin ${ }^{(24,34,38,61)}$. This study did not present any different results, despite the small number of patients treated with pegylated interferon. When a logistics regression analysis was made, a statistically significant association was found between type of interferon used and SVR.

In conclusion, steatosis did not seem to influence SVR in our group of patients treated for $\mathrm{CHC}$ with interferon and ribavirin. 
Piccoli LZ, Mattos AA, Coral GP, Mattos AZ, Santos DE. Análise da resposta virológica sustentada em pacientes com hepatite crônica pelo vírus da hepatite C e esteatose hepática. Arq Gastroenterol. 2011;48(3):179-85.

RESUMO - Contexto - Tanto a hepatite crônica pelo vírus C quanto a doença hepática gordurosa não-alcoólica são reconhecidas como causas frequentes de doença hepática nos países ocidentais. É comum observar a concomitância das duas doenças e a influência da esteatose na resposta virológica sustentada dos pacientes com hepatite crônica pelo vírus C. Objetivo - Avaliar a resposta virológica sustentada nos pacientes com hepatite crônica pelo vírus $\mathrm{C}$ de acordo com a presença de esteatose. Métodos - Foram avaliados, retrospectivamente, 160 pacientes com hepatite crônica C. Dados demográficos, como sexo, idade, índice de massa corpórea, presença de diabetes mellitus e hipertensão arterial sistêmica, genótipo do vírus e uso de interferon peguilado foram analisados, bem como o estadiamento e a presença de esteatose, quando da histologia. Resultados - A maioria dos pacientes era masculina (57,5\%), com média de idade de 48 anos $\pm 9,7$. O genótipo mais frequente foi o 3 (56,9\%) e, na avaliação histológica, foi observada esteatose em $65 \%$ dos pacientes (104/160). A resposta virológica sustentada nos pacientes com esteatose foi de $38,5 \%$, sendo de $32,1 \%$ nos pacientes sem esteatose $(P=0,54)$. Quando se analisaram possíveis fatores associados à presença de esteatose, somente índice de massa corpórea $\mathrm{e}$ hipertensão arterial sistêmica estiveram associados de forma significativa. Quando se avaliaram em regressão logística os fatores que influenciaram a resposta virológica sustentada, genótipo e uso de interferon peguilado mostraram-se fatores independentes associados à resposta. Conclusão - A presença de esteatose hepática não influenciou a resposta virológica sustentada de pacientes com hepatite crônica pelo vírus $\mathrm{C}$ tratados com interferon e ribavirina.

DESCRITORES - Hepatite C crônica. Fígado gorduroso. Antivirais.

\section{REFERENCES}

1. Adinolfi LE, Gambardella M, Andreana A, Tripodi MF, Utili R, Riggiero G Steatosis accelerates the progression of liver damage of chronic hepatitis $\mathrm{C}$ patients and correlates with specific HCV genotype and visceral obesity. Hepatology. 2001;33:1358-64.

2. Adinolfi LE, Utili R, Andreana A, Tripodi MF, Utili R, Ruggiero G. Serum HCV RNA levels correlate with histological liver damage and concur with steatosis in progression of chronic hepatitis C. Dig Dis Sci. 2001;46:1677-83.

3. Adinolfi LE, Durante-Mangoni E, Zampino R, Ruggiero G. Hepatitis C virusassociated steatosis - pathogenic mechanisms and clinical implications [review article]. Aliment Pharmacol Ther. 2005;22:52-5.

4. Almeida PRL, Mattos AA; Peixoto MF, Both CT. Estudo clínico, laboratorial e histológico em doadores de sangue anti-HCV positivos. GED Gastroenterol Endosc Dig. 1999; 18:85-90.

5. American Diabetes Association. Clinical practice recommendations 2000. Diabetes Care. 2000;23(suppl 1):1-116.

6. Angulo P, Keach JC, Batts KP, Lindor KD. Independent predictors of liver fibrosis patients with nonalcoholic steatohepatitis. Hepatology. 1999;30:1356-62.

7. Angulo P. Nonalcoholic fatty liver disease. N Engl J Med. 2002;346:1221-31.

8. Asselah T, Boyer N, Guimont MC, Cazals-Hatem D, Tubach F, Nahon K, Daïkha H. Vidaud D, Martinot M, Vidaud M, Degott C, Valla D, Marcellin P. Liver fibrosis is not associated with steatosis but with necroinflammation in French patients with chronic hepatitis C. Gut. 2003;52:1638-43.

9. Bach N, Thung SN, Schaffner F. The histological features of chronic hepatitis $\mathrm{C}$ and autoimmune chronic hepatitis a comparative analysis. Hepatology. 1992; 15:572-7.

10. Bressler BL, Guindi M, Tomlinson G, Heathcote J. High body mass index is an independent risk factor for o response to antiviral treatment in chronic hepatitis C. Hepatology. 2003;38:639-44.

11. Brunt EM. Nonalcoholic steatohepatitis: definition and pathology. Semin Liver Dis. 2001;21:3-16.

12. Castéra L, Hézode C, Roudot-Thoraval F, Bastie A, Zafrani ES, Pawlotsky JM, Dhumeaux D. Worsening of steatosis in an independent factor of fibrosis progression in untreated patients with chronic hepatitis $\mathrm{C}$ and paired liver biopsies. Gut. 2003;52:288-92.

13. Castéra L, Hézode C, Roudot-Thoraval F, Lonjon I, Zafrani ES, Pawlotsky JM, Dhumeaux D. Effect of antiviral treatment on evolution of liver steatosis in patients with chronic hepatitis $\mathrm{C}$ : indirect evidence of a role of hepatitis $\mathrm{C}$ virus genotype 3 in steatosis. Gut. 2004;53:420-4.

14. Castéra L, Chouteau P, Hezode C, Zafrani ES, Dhumeaux D, Pawlotsky JM. Hepatitis C virus-induced hepatocellular steatosis. Am J Gastroenterol. 2005;100:711-5.

15. Clark JM, Brancati FL, Diehl AM. Nonalcoholic fatty liver disease. Gastroenterology. 2002;122:1649-57.
16. Clinical guidelines on the identification, evaluation, and treatment of overweight and obesity in adults: executive summary. Expert panel on the identification, evaluation, and treatment of overweight in adults. Am J Clin Nutr. 1998;68:899-917.

17. Coral G, de Mattos AA, de Mattos AZ, dos Santos DE. [Steatosis and nonalcoholic steatohepatitis in patients with chronic hepatitis due to hepatitis $\mathrm{C}$ virus infection]. Arq Gastroenterol. 2006;43:265-8.

18. Cross TJ, Quaglia A, Nolan J, Hughes S, Harrison PM. Do steatosis and steatohepatitis impact on sustained virological response (SVR) rates in patients receiving pegylated interferon and ribavirin for chronic hepatitis $\mathrm{C}$ infection? J Med Virol. 2010;82:958-64

19. Czaja AJ, Carpenter HA, Santrach PJ, Moore SB. Host and disease specific factors affecting steatosis in chronic hepatitis C. J Hepatol. 1998;29:198-206.

20. Day CP, James OF. Hepatitic steatosis: innocent bystander of guilty party? Hepatology. 1998;27:1463-66.

21. de Almeida PR, de Mattos AA, Amaral KM, Feltrin AA, Zamin P, Tovo CV, Picon PD. Treatment of hepatitis $C$ with peginterferon and ribavirin in a public health program. Hepatogastroenterology. 2009;56:223-6.

22. Fartoux L, Chazouillères O, Wendum D, Poupon R, Serfaty L. Impact of steatosis on progression of fibrosis in patients with mild hepatitis C. Hepatology. 2005;41:82-7.

23. Fartoux L, Poujol-Robert A, Guéchot J, Wendum D, Poupon R, Serfaty L. Insulin resistance is a cause of steatosis and fibrosis progression in chronic hepatitis $\mathrm{C}$. Gut. 2005;54:1003-8.

24. Fried MW, Shiffman ML, Reddy KR, Smith C, Marinos G, Gonçalves FL Jr, Häussinger D, Diago M, Carosi G, Dhumeaux D, Craxi A, Lin A, Hoffman J, Yu J. Peginterferon alfa-2a plus ribavirina for chronic hepatitis $\mathrm{C}$ virus infection. N Engl J Med. 2002;347:975-82.

25. Friedenberg F, Pungpapong S, Zaeri N, Braitman L. The impact of diabetes and obesity on liver histology in patients with hepatitis C. Diabetes Obes Metab. 2003;5:150-5.

26. Hourigan LF, MacDonald GA, Purdie D, Whitehall VH, Shorthouse C, Clouston A, Powell EE. Fibrosis in chronic hepatitis $\mathrm{C}$ correlates significantly with body mass index and steatosis. Hepatology. 1999;29:1215-9.

27. Hu KQ, Currie SL, Shen H, Cheung RC, Ho SB, Bini EJ, McCracken JD, Morgan T, Bräu N, Schmidt WN, Jeffers L, Wright T. Clinic implications of hepatic steatosis in patients with chronic hepatitis C: a multicenter study of U.S. Veterans. Dig Dis Sci. 2007;52:570-8.

28. Hui JM, Kench J, Farrell GC, Lin R, Samarasinghe D, Liddle C, Byth K, George J. Genotype-specific mechanisms for hepatic steatosis in chronic hepatitis C infection. J Gastroenterol Hepatol. 2002;17:873-81.

29. Hwang SJ, Luo JC, Chu CW, Lai CR, Lu CL, Tsay SH, Wu JC, Chang FY, Lee $\mathrm{SD}$. Hepatic steatosis in chronic hepatitis $\mathrm{C}$ virus infection: prevalence and clinical correlation. J Gastroenterol Hepatol. 2001;16:190-5.

30. Intraobserver and interobserver variations in liver biopsy interpretation in patients with chronic hepatitis C. The French Metavir Cooperative Study Group. Hepatology. 1994;20:15-20. 
31. Jian Wu Y, Shu Chen L, Gui-Qiang W. Effects of fatty liver and related factors on efficacy of combination antiviral therapy in patients with chronic hepatitis $\mathrm{C}$. Liver Int. 2006;26:166-72.

32. Leandro G, Mangia A, Hui J, Fabris P, Rubbia-Brandt L, Colloredo G, Adinolfi LE, Asselah T, Jonsson JR, Smedile A, Terrault N, Pazienza V, Giordani MT, Giostra E, Sonzogni A, Ruggiero G, Marcellin P, Powell EE, George J, Negro F Relationship between steatosis, inflammation, and fibrosis in chronic hepatitis C: a meta-analysis of individual patients data. Gastroenterology. 2006;130:1636-42.

33. Lonardo A, Loria P, Adinolfi LE, Carulli N, Ruggiero G. Hepatitis C and steatosis: a reappraisal. J Viral Hepat. 2006;13:73-80.

34. Manns MP, Mchutchison JG, Gordon SC, Rustgi VK, Schiffman M, Reindollar R, Goodman ZD, Koury K, Ling M, Albrecht JK. Peginterferon alfa-2b plus ribavirin compared with interferon alfa-2b plus ribavirin for initial treatment of chronic hepatitis C: a randomized trial. Lancet. 2001;358:958-65.

35. Mello V, Cruz T, Nuñez G, Simões MT, Ney-Oliveira F, Braga H, Araújo C, Cunha S, Schinoni MI, Cruz M, Parana R. Peripheral insulin resistance during treatment of chronic hepatitis $\mathrm{C}$ with peguilated interferon plus ribavirin. $\mathrm{J}$ Med Virol. 2006;78:1406-10.

36. Mihm S, Fayyazi A, Hartmann H, Ramadori G. Analysis of histopathologica manifestations of chronic hepatitis $\mathrm{C}$ virus infection with respect to virus genotype. Hepatology. 1997;25:735-9.

37. Monto A, Alonzo J, Watson JJ, Grunfeld C, Wright TL. Steatosis in chronic hepatitis $\mathrm{C}$ : relative contributions of obesity, diabetes mellitus and alcohol. Hepatology. 2002;36:729-36.

38. National Institute of Health Consensus Development Conference Statement. Management of hepatitis C: 2002 - June 10-12, 2002. Hepatology. 2003;36: s3-20.

39. Parise ER, Oliveira AC. [Insulin resistance in chronic hepatitis C]. Arq Gastroenterol 2007:44:178-84.

40. Patton HM, Patel K, Behling C, Bylund D, Blatt LM, Vallée M, Heaton S, Conrad A, Pockros PJ, McHutchison JG. The impact of steatosis on disease progression and early sustained treatment response in chronic hepatitis $\mathrm{C}$ patients. J Hepatol. 2004;40:484-90.

41. Poynard T, Bedossa P, Opolon P. Natural history of liver fibrosis progression in patients with chronic hepatitis C. The OBSVIRC, METAVIR, CLINIVIR, and DOSVIRC group. Lancet. 1997;349:825-32.

42. Poynard T, Ratziu V, McHutchison J, Manns M, Goodman Z, Zeuzem S, Younoss $\mathrm{Z}$, Albrecht J. Effect of treatment with peginterferon or interferon alfa-2b and ribavirina on steatosis in patients infected with hepatitis C. Hepatology. 2003;38:75-85

43. Rubbia-Brandt L, Quadri R, Abid K, Giostra E, Malé PJ, Mentha G, Spahr L, Zarski JP, Borisch B, Hadengue A, Negro F. Hepatocyte steatosis is a cytopathic effect of hepatitis C virus genotype 3. J Hepatol. 2000;33:106-15.

44. Rubbia-Brandt L, Leandro G, Spahr L, Giostra E, Quadri R, Male PJ, Negro F. Liver steatosis in chronic hepatitis $\mathrm{C}$ : a morphological sign suggesting infection with HCV genotype 3. Histopathology. 2001;39:119-24.

45. Rubbia-Brandt L, Fabris P, Pagnanin S, Leandro G, Male PJ, Giostra E, Carlotto A, Bozzola L, Smedile A, Negro F. Steatosis affects chronic hepatitis C progression in a genotype specific way. Gut. 2004;53:406-12.

46. Sanyal AJ, Contos MJ, Sterling RK, Luketic VA, Shiffman ML, Stravitz RT, Mills AS. Nonalcoholic fatty liver disease in patients with hepatitis $\mathrm{C}$ is associated with features of the metabolic syndrome. Am J Gastroenterol. 2003;98:2064-71.
47. Sanyal AJ. Nonalcoholic fatty liver disease and hepatitis $\mathrm{C}$ - risk factors and clinical implications [review article]. Aliment Pharmacol Ther. 2005;22: 48-51.

48. Serfaty L, Andreani T, Giral P, Carbonell N, Chazouillères O, Poupon R. Hepatitis $\mathrm{C}$ virus induced hypobetalipoproteinemia: a possible mechanism for steatosis in chronic hepatitis C. J Hepatol. 2001;34:428-34.

49. Serfaty L, Poujol-Robert A, Carbonell N, Chazouillères O, Poupon RE, Poupon R. Effect of the interaction between steatosis and alcohol intake on liver fibrosis progression in chronic hepatitis C. Am J Gastroenterol. 2002;97:1807-12.

50. Simmonds P. Variability of hepatitis C virus. Hepatology. 1995;21:570-83.

51. The sixth report of the Joint National Committee on prevention, detection, evaluation, and treatment of high blood pressure. Arch Intern Med. 1997; 157:2413-46.

52. Solis-Herruzo JA, Pérez-Carreras M, Rivas E, Fernández-Vásquez I, Garfia C, Bernardos E, Castellano G, Colina F. Factors associated with the presence of nonalcoholic steatohepatitis in patients with chronic hepatitis C. Am J Gastroenterol. 2005;100:1091-8

53. Soresi M, Tripi S, Franco V, Giannitrapani L, Alessandri A, Rappa F, Vuturo O, Montalto G. Impact of liver steatosis on the antiviral response in the hepatitis C virus-associated chronic hepatitis. Liver Int. 2006;26:1119-25.

54. Stuyver L, Rossau R, Wyseur A, Duhamel IM, Vanderborgth B, van Heuverswyn $\mathrm{H}$, Maertens $\mathrm{G}$. Typing of hepatitis $\mathrm{C}$ virus isolates and characterisation of new subtypes using a line probe assay. J Gen Virol.1993;74:1093-102.

55. Thomopoulos KC, Theocharis GJ, Tsamantas AC, Siagris D, Dimitropoulou D, Gogos C, Labropoulou-Karatza C. Liver steatosis is an independent risk factor for treatment failure in patients with chronic hepatitis C. Eur J Gastroenterol Hepatol. 2005; 17:149-53.

56. Tong MJ, Hwang SJ, Lefkowitz M, Lee SD, Co RL, Conrad A, Schmid P, Lo KJ Correlation of serum HCV-RNA and alanine aminotransferases levels in chronic hepatitis $\mathrm{C}$ patients during treatment with ribavirin. J Gastroenterol Hepatol. 1994;9:587-91.

57. Westin J, Nordlinder H, Lagging M, Norkrans G, Wejstal R. Steatosis accelerates fibrosis development over time in hepatitis $\mathrm{C}$ virus genotype 3 infected patients. J Hepatol. 2002;37:837-42

58. Westin J, Lagging M, Dhillon AP, Norkrans G, Romero AI, Pawlotsky JM, Zeuzem S, Schalm SW, Verheij-Hart E, Negro F, Missale G, Neumann AU, Hellstrand K for the DITTO-HCV Group. Impact of hepatic steatosis on viral kinetics and treatment outcome during antiviral treatment of chronic HCV infection. J Viral Hepat. 2007;14:29-35.

59. Younossi ZM, Mccullough A, Ong PJ, Barnes DS, Post A, Tavill A, Bringman D, Martin LM, Assmann J, Gramlich T, Mullen KD, O'Shea R, Carey WD, Ferguson R. Obesity and non-alcoholic fatty liver disease in chronic hepatitis C. J Clin Gastroenterol. 2004;38:705-9.

60. Zamin I Jr, de Mattos AA, Zettler CG. Nonalcoholic steatohepatitis in nondiabetic obese patients. Can J Gastroenterol. 2002;16:303-7.

61. Zeuzem S, Hultcrantz R, Bourliere M, Goeser T, Marcellin P, Sanchez-Tapias J, Sarrazin C, Harvey J, Brass C, Albrecht J. Peginterferon alfa-2b plus ribavirina for treatment of chronic hepatitis $C$ in previously untreated patients infected with HCV genotype 2 or 3. J Hepatol. 2004;40:993-9.

Received 25/10/2010 Accepted 13/1/2011. 